\title{
The Fate of Ammonia and Hydrogen Cyanide During Flameless Combustion of Low Calorific Value Gases*
}

\author{
Mariusz Zieba $^{a^{* * *}}$, Mathias Fink ${ }^{a}$, Anja Schuster ${ }^{a}$, Günter Scheffknecht ${ }^{a}$ and Roland Berger ${ }^{\mathrm{b}}$ \\ ${ }^{\mathrm{a}}$ Institute of Combustion and Power Plant Technology (IFK), University of Stuttgart, Germany \\ be-flox GmbH, Renningen, Germany \\ E-mail: mariusz.zieba@ifk.uni-stuttgart.de
}

\begin{abstract}
In this paper, a review of the experimental investigations on the fuel- $\mathrm{NO}_{\mathrm{x}}$ formation during flameless combustion is presented. The first series of experiments described in the paper were conducted using ammonia doped synthetic gases with different compositions. During these experiments, the influence of gas composition on the conversion of ammonia $\left(\mathrm{NH}_{3}\right)$ to $\mathrm{NO}_{\mathrm{x}}$ is investigated. The second series of experiments were conducted using product gas generated in a fluidized bed gasifier. These results show the dependencies between the gasifier operating parameters, product gas composition and final $\mathrm{NO}_{\mathrm{x}}$ emissions. Moreover, the concentrations of the ammonia and hydrogen cyanide $(\mathrm{HCN})$ in the product gas were measured in order to calculate the conversion ratios of these compounds to $\mathrm{NO}_{\mathrm{x}}$. The results show the significant influence of the gas composition and the gasifier process parameters on the final $\mathrm{NO}_{\mathrm{x}}$ emissions. In particular, the hydrocarbon content influences the ammonia to $\mathrm{NO}_{\mathrm{x}}$ conversion. The lowest $\mathrm{NO}_{\mathrm{x}}$ emissions and therefore the lowest conversion ratios were measured while burning gases with a low hydrocarbon content. An increase of the hydrocarbon concentration in the gas corresponded to a rapid increase in the conversion ratios.
\end{abstract}

Keywords: Fuel-NO ; Flameless Combustion.

\section{Introduction}

The wide-ranging applicability of the Flameless oxidation $\left(\mathrm{FLOX}^{\circledR}\right)$ technology for the utilization of natural and low calorific value gases has already been proven and reported in the literature (Wünning at al.,1997; Galleti et al., 2007; Cavaliere et al., 2004). This technology became of interest due to its great potential in reducing thermal nitrogen oxides (thermal- $\mathrm{NO}_{\mathrm{x}}$ ) while burning natural gas. In addition to excellent burnout, the fact that fluctuations in the fuel composition do not lead to combustion instabilities is a reason for the high interest in combusting low calorific value gases (LCV) in flameless burners. However, the tests with biogenous gaseous fuels have shown a limited ability to reduce $\mathrm{NO}_{\mathrm{x}}$, where most of the $\mathrm{NO}_{\mathrm{x}}$ emissions originate from the fuel-bound nitrogen (Schuster et al., 2007a, Schuster et al., 2007b). During the gasification processes, the nitrogen contained in the solid fuel is partly released to the product gases as ammonia $\left(\mathrm{NH}_{3}\right)$ or hydrogen cyanide (HCN). These compounds are formed as a result of thermal destruction of proteins and amino acids contained in the biomass (Leppälahti et al., 1995; Becidan et al., 2007). The $\mathrm{NH}_{3}$ and $\mathrm{HCN}$ compounds are either converted to $\mathrm{NO}_{\mathrm{x}}$ or reduced to neutral $\mathrm{N}_{2}$ in the combustion process. The selectivity of this process depends on the gas composition, temperature and mixing of the reactants during combustion. In this paper, a review of the experimental investigations on the fuel- $\mathrm{NO}_{\mathrm{x}}$ formation during flameless combustion is presented. The first series of experiments described in the paper were conducted using synthetic gases with different compositions. During these experiments, ammonia was added to the fuel stream in order to investigate the fuel nitrogen conversion. The aim of these experiments was to investigate the influence of the gas composition on the conversion of ammonia to $\mathrm{NO}_{\mathrm{x}}$. Moreover, experiments in which product gas generated in a bubbling fluidized bed (BFB) gasifier is subsequently combusted in a $\mathrm{FLOX}^{\circledR}$ Burner are presented. Since the gasifier product gas composition depends on the gasification process parameters such as air ratio (AR) and temperature, the final $\mathrm{NO}_{\mathrm{x}}$ concentration is also influenced by these factors. The aim of these experiments was to investigate the dependences between gasifier operating parameters, the product gas composition (combustibles, $\mathrm{NH}_{3}$ and $\mathrm{HCN}$ concentration) and final $\mathrm{NO}_{\mathrm{x}}$ emissions during flameless combustion of these gases.

\section{Experimental}

In this section the test rigs, the tested fuels as well as the analysis and measurement methods are presented.

\subsection{Burner test rig}

The experimental facility consists of a $20 \mathrm{~kW} \mathrm{FLOX}^{\circledR}$ Burner coupled either with the gas mixing unit during experiments with synthetic gases or with the fluidized bed gasifier during experiments with solid fuels. The burner shown in Figure 1 has been originally developed for natural gas and was subsequently modified to combust low calorific value gases. During start-up the combustion chamber is heated in flame mode up to $850{ }^{\circ} \mathrm{C}$ using natural gas. Above this temperature the burner can be switched to flameless mode and fired either with low calorific value gas prepared in the gas mixing unit or with product gas generated in the gasifier. The combustion air is preheated while passing through a ceramic recuperator pipe. The temperature of the combustion chamber is controlled using an air-cooled pipe. In flameless burners the preheated

This paper is an updated version of a paper published in the ECOS'10 proceedings. It is printed here with permission of the authors and organizers. 
combustion air is introduced separately to the fuel into the combustion chamber. The air velocity of about 70 to 100 $\mathrm{m} / \mathrm{s}$ causes high internal recirculation of the hot flue gases. These hot products are partially mixed with the fuel and oxidizer before the mixture ignites. As a result, there is no identifiable flame front. The reactants are strongly diluted and the temperature field is homogeneous without high peaks (Wünning at al.,1997).

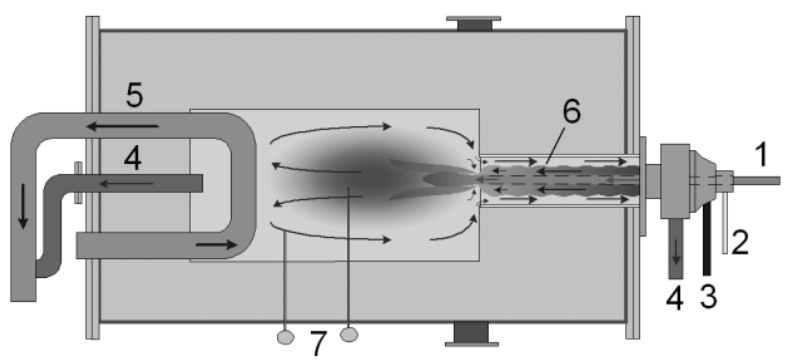

Figure 1. Scheme of FLOX ${ }^{\circledR}$-Burner test rig (1 - natural gas or LCV gas with ammonia, 2 - natural gas, 3 combustion air, 4 - flue gas, 5 - cooling pipe, 6 recuperator pipe, 7 - thermocouples).

\subsection{Gas mixing unit}

The gas mixing unit, where the fuel gas is prepared, allows mixing of $\mathrm{CH}_{4}, \mathrm{CO}, \mathrm{CO}_{2}, \mathrm{H}_{2}$ and $\mathrm{N}_{2}$. The flow of each gas is controlled by a digital mass flow controller. The gases were mixed and supplied to the burner at room temperature. Additionally, ammonia was introduced to the fuel stream to simulate the fuel nitrogen oxides precursors.

\subsection{Bubbling Fluidised Bed (BFB) gasifier}

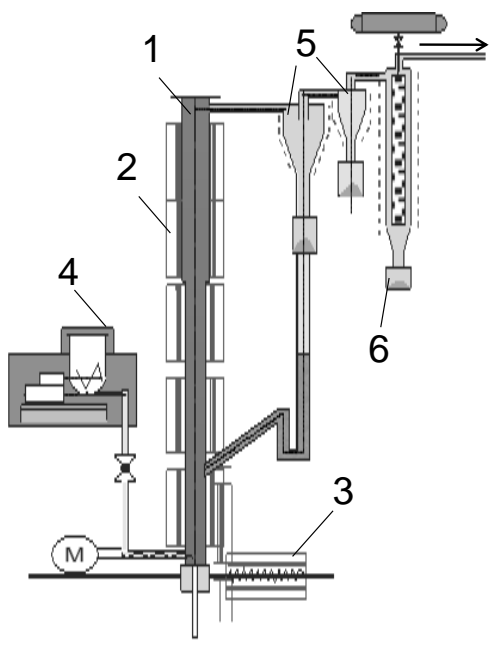

Figure 2. Scheme of BFB gasifier $(1$-reactor tube, 2 electrical heaters, 3 -air preheater, 4-fuel feeding unit, 5 - cyclones, 6-candle filter).

The reactor shown in Figure 2 is made of hightemperature steel and is heated by five electrical heating zones which can be controlled separately. The heating zone at the bottom of the reactor vessel, where the bed material is fluidized and the biomass is fed has a heating capacity of $11 \mathrm{~kW}_{\mathrm{el}}$. Every other heating zone above has a heating capacity of $4 \mathrm{~kW}_{\mathrm{el}}$. The maximum heating zone temperature is $1000{ }^{\circ} \mathrm{C}$, while the resulting maximum process temperature can be $950{ }^{\circ} \mathrm{C}$. The fluidization air can be preheated up to $900{ }^{\circ} \mathrm{C}$ in a two zone electrical gas preheater. The absolute pressure in the BFB is controlled by a pressure control valve in the range of $0-100$ mbar. The fuel feeding system is a screw feeder system where the fuel volume flow rate is controlled. The fuel rate can be set between 1 and maximum $7 \mathrm{~kg} / \mathrm{h}$ depending on the type of fuel used. The product gas exits the reactor vessel and proceeds to two electrically heated cyclones connected in series, followed by a candle filter. As a result, dragged particles like ashes, char and bed material are removed. After the candle filter, a part of the product gas is led through a suction point to gas analysis. The main part of the product gas is led via a stainless steel pipe heated to $350{ }^{\circ} \mathrm{C}$ to the FLOX $^{\circledR}$-Burner.

\subsection{Fuel composition - experiments with synthetic gases}

During typical air gasification the main combustible components in the product gas are carbon monoxide and hydrogen. The amount of methane and higher hydrocarbons is usually relatively small. However, the composition of the gasification product gas depends on the solid fuel used, gasifier operating parameters and gasifier type. During the experiments with synthetic gases the composition of the investigated fuels is similar to the product gases from the gasification processes. In order to cover such a wide range of different gas compositions three synthetic gases with $\mathrm{CO} / \mathrm{H}_{2}$ ratios of $0.5,0.7$ and 1.5 were investigated. For each of the $\mathrm{CO} / \mathrm{H}_{2}$ ratios, the methane content was varied between 0 and 10 vol- $\%$ to investigate the influence of hydrocarbons on the ammonia to $\mathrm{NO}_{\mathrm{x}}$ conversion. The concentration of $\mathrm{CO}$ and $\mathrm{H}_{2}$ was kept constant for each $\mathrm{CO} / \mathrm{H}_{2}$ ratio. Therefore, increasing the methane content in the mixture led to a decrease in nitrogen $\left(\mathrm{N}_{2}\right)$ concentration and an increase in lower heating value of the fuel. The ammonia concentration of 700 ppmv was constant for all experiments. This concentration is related to the total mixture of fuel and combustion air to ensure the same ammonia partial pressure for each mixture. All of the mentioned experiments were carried out at the same power input of $18 \mathrm{~kW}$. The compositions of the tested synthetic fuels are summarized in Table 1.

Table 1. Composition and lower heating value (LHV) of the synthetic fuels.

\begin{tabular}{lllll}
\hline & & Gas 1 & Gas 2 & Gas 3 \\
\hline $\mathrm{CO}$ & $($ vol-\%) & 18 & 18 & 27 \\
$\mathrm{H}_{2}$ & $($ vol-\%) & 16 & 25 & 18 \\
$\mathrm{CO}_{2}$ & $($ vol-\%) & 15 & 15 & 15 \\
$\mathrm{CH}_{4} \quad($ vol-\%) & $0-10$ & $0-10$ & $0-10$ \\
$\mathrm{CO} / \mathrm{H}_{2}(-)$ & 0.5 & 0.7 & 1.5 \\
$\mathrm{LHV}$ & $\left(\mathrm{MJ} / \mathrm{m}^{3}{ }_{\text {stp }}\right)$ & $6.2-9.7$ & $5.0-8.5$ & $5.4-8.9$ \\
$\mathrm{NH}_{3} \quad(\mathrm{ppmv})$ & 700 & 700 & 700 \\
\hline
\end{tabular}

\subsection{Solid fuel composition and gasifier settings - experiments using BFB gasifier}

In the second series of experiments the flameless burner was fired using product gas from the gasifier. Wood pellets and rape cake pellets were used as a fuel for the tests. During the experiments air was used as a gasification agent. The characteristics of the solid fuels are given in Table 2 .

The rape cake pellets were chosen due to the high nitrogen content in the fuel. Both of the presented fuels were gasified under two different temperatures and gasifier air ratios. All experimental conditions are presented in Table 3 . 
Table 2. Characteristics of the tested biomass.

\begin{tabular}{llcc}
\hline & & $\begin{array}{c}\text { Wood } \\
\text { pellets }\end{array}$ & Rape cake pellets \\
\hline Moisture & $($ wt-\% ar) & 7.36 & 8.10 \\
Ash & $($ wt-\% ar) & 0.54 & 5.94 \\
$\mathrm{C}$ & $($ wt-\% ar) & 46.43 & 45.00 \\
$\mathrm{H}$ & $($ wt-\% ar) & 5.77 & 6.67 \\
$\mathrm{~N}$ & $(\mathrm{wt}-\%$ ar $)$ & $<0.3$ & 4.98 \\
$\mathrm{~S}$ & $(\mathrm{wt}-\%$ ar $)$ & $<0.3$ & 0.48 \\
LHV & $(\mathrm{MJ} / \mathrm{kg} \mathrm{dm})$ & 20.20 & 17.76 \\
\hline
\end{tabular}

Table 3. Gasifier operating parameters.

\begin{tabular}{lcc}
\multirow{2}{*}{ Fuel } & \multicolumn{2}{c}{ Gasification parameters } \\
& $\mathrm{T}\left({ }^{\circ} \mathrm{C}\right)$ & Air Ratio \\
\hline \multirow{2}{*}{ Wood pellets } & \multirow{2}{*}{750} & 0.15 \\
& & 0.22 \\
\cline { 2 - 3 } & \multirow{2}{*}{875} & 0.15 \\
Rape cake pellets & 750 & 0.22 \\
\hline
\end{tabular}

\subsection{Analysis and measurement methods}

In order to evaluate the fuel- $\mathrm{N}$ conversion ratios to $\mathrm{NO}_{\mathrm{x}}$ the following equation was applied

$$
C R_{N \rightarrow N O x}=\frac{\left[N O_{x}\right]_{\text {fluegas }} \cdot \dot{V}_{\text {fluegas }}}{[N]_{\text {fuel }} \cdot \dot{V}_{\text {fuel }}},
$$

where: $\left[N O_{x}\right]_{\text {fluegas }}-\mathrm{NO}_{\mathrm{x}}$ concentration in the flue gas in $\operatorname{ppmv}_{\text {dry }},[N]_{\text {fuel }}$ - concentration of $\mathrm{NH}_{3}$ and $\mathrm{HCN}$ in the fuel in $\mathrm{ppmv}_{\text {dry }}, \dot{V}_{\text {fluegas }}$ - flue gas flow in $\mathrm{m}^{3}{ }_{\text {stp }} / \mathrm{h}, \dot{V}_{\text {fuel }}$ fuel flow in $\mathrm{m}_{\text {stp }}^{3} / \mathrm{h}$. During all tests the exhaust gas was continuously sampled and analysed at the combustion chamber exit with respect to $\mathrm{O}_{2}, \mathrm{CO}_{2}, \mathrm{CO}, \mathrm{NO}, \mathrm{NO}_{2}$ and $\mathrm{NO}_{\mathrm{x}}$. During the experiments in which the burner was coupled with the gasifier the product gas was analyzed continuously with respect to $\mathrm{CO}, \mathrm{CO}_{2}, \mathrm{CH}_{4}, \mathrm{H}_{2}$ and $\mathrm{O}_{2}$. Moreover, a gas chromatograph was used to determine the content of ethene $\left(\mathrm{C}_{2} \mathrm{H}_{4}\right)$, ethane $\left(\mathrm{C}_{2} \mathrm{H}_{6}\right)$ and propene $\left(\mathrm{C}_{3} \mathrm{H}_{6}\right)$. The ammonia and hydrogen cyanide concentrations in the product gas were measured in order to investigate the dependencies between gasifier operating parameters, product gas composition (combustibles, $\mathrm{NH}_{3}$ and $\mathrm{HCN}$ concentration) and final $\mathrm{NO}_{\mathrm{x}}$ emission during flameless combustion of these gases. The concentration of ammonia and hydrogen cyanide was measured using the wet chemistry method. The product gas was sampled in the vicinity of the burner inlet. The gas sampling pipe was heated up to $350{ }^{\circ} \mathrm{C}$ to avoid ammonia and tar condensation. The gas was flowing through a heated filter and was led to three impinger bottles placed in an ice bath. A $0.01 \mathrm{M} \mathrm{H}_{2} \mathrm{SO}_{4}$ solution was used for ammonia and a $2 \mathrm{M}$ $\mathrm{NaOH}$ solution was used for hydrogen cyanide absorption. The gas flow, temperature, pressure and oxygen concentration in the gas was measured to ensure high quality of the sampling. The content of $\mathrm{NH}_{3}$ and $\mathrm{HCN}$ in the solutions was afterwards analysed according to DIN38406, (1983) and DIN38405, (1981). For each gasifier setting two gas samples were collected. The content of $\mathrm{NH}_{3}$ and $\mathrm{HCN}$ is given as an average value of the analysed samples.

\section{Results}

In this section the experimental results achieved using ammonia doped synthetic gases and product gases generated in the BFB gasifier are presented.

\subsection{NOx emission during NH3 doped synthetic gas combustion}

In order to investigate the dependencies between hydrocarbon concentrations in the fuel and fuel nitrogen to $\mathrm{NO}_{\mathrm{x}}$ conversion, experiments with a varying methane content were conducted. The air ratio was set to 1.5 . Since the high dilution of the reaction zone caused by the internal recirculation of the hot flue gases significantly decreases the temperature peaks in the chamber, the combustion of all tested fuel mixtures occurs at a very similar and homogeneous temperature. When increasing the methane content the temperature was slightly changing in the range of 960 to $980{ }^{\circ} \mathrm{C}$. However, such small temperature differences do not have a considerable influence on ammonia to $\mathrm{NO}_{\mathrm{x}}$ conversion ratios (Zieba et al., 2009b). Figure 3 shows the $\mathrm{NO}_{\mathrm{x}}$ concentration in the flue gas for three different $\mathrm{CO} / \mathrm{H}_{2}$ ratios as a function of methane concentration in the fuel. A rapid increase of $\mathrm{NO}_{x}$ emissions can already be observed at the lowest investigated methane concentrations of about $1 \mathrm{vol}-\%$. At the methane concentration of approx. 2 vol- $\%$ the slope of the trend curve decreases. However, the $\mathrm{NO}_{\mathrm{x}}$ emissions increase with increasing methane concentration across the whole investigated range. The measured $\mathrm{NO}_{\mathrm{x}}$ emissions are higher in gases with a lower $\mathrm{CO} / \mathrm{H}_{2}$ ratio.

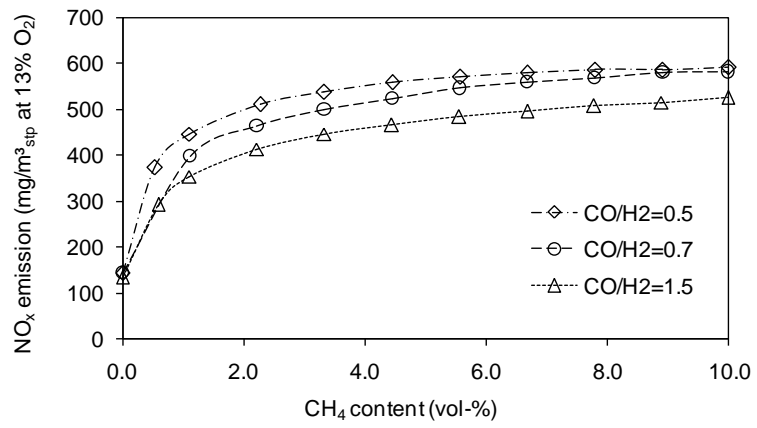

Figure 3. $N O_{x}$ concentration in the flue gas as a function of methane concentration in the fuel; $\left(t_{\text {comb }}=970{ }^{\circ} \mathrm{C}, \mathrm{AR}=1.5\right)$.

Figure 4 presents the calculated ammonia to $\mathrm{NO}_{\mathrm{x}}$ conversion ratios. The results show that the investigated $\mathrm{CO} / \mathrm{H}_{2}$ ratios had no significant influence on the conversion ratios. The higher $\mathrm{NO}_{\mathrm{x}}$ emissions by lower $\mathrm{CO} / \mathrm{H}_{2}$ ratios were observed due to the changing content of water vapour in the flue gas resulting from the hydrogen oxidation. Varying the methane concentration, the conversion ratios increase from about 0.16 for methane-free mixtures to above 0.6 , when 10 vol- $\%$ of methane was present in the fuel.

In order to investigate the influence of the burner air ratio on the $\mathrm{NO}_{\mathrm{x}}$ emissions, ammonia doped fuel with a $\mathrm{CO} / \mathrm{H}_{2}$ ratio of 0.7 and varying methane concentration was burned at two different air ratios of 1.3 and 1.6. The methane content was varied between 0 and 4.5 vol- $\%$. Figure 5 shows the $\mathrm{NO}_{\mathrm{x}}$ emissions obtained in these experiments. The tests were carried out at $970{ }^{\circ} \mathrm{C}$, with a 
power input of $18 \mathrm{~kW}$. Similar to the previous experiments the $\mathrm{NO}_{\mathrm{x}}$ emissions increased with increasing methane content in the fuel for both investigated air ratios. However, for methane-free mixtures the air ratio had a minor influence on the $\mathrm{NO}_{\mathrm{x}}$ emissions. Increasing the methane content in the fuel saw the influence of burner air ratio slightly increase.

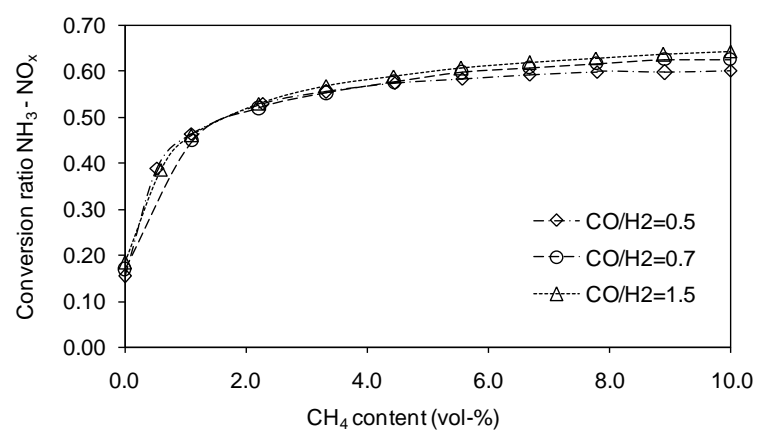

Figure 4. Ammonia to $\mathrm{NO}_{x}$ conversion ratio as a function of methane concentration in the fuel; $\left(t_{\text {comb }}=970^{\circ} \mathrm{C}\right.$, $A R=1.5$ ).

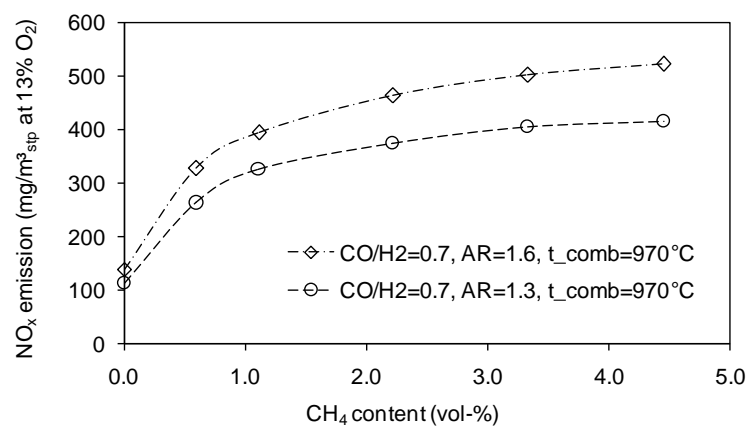

Figure 5. $\mathrm{NO}_{x}$ concentration in the flue gas as a function of methane concentration in the fuel; $\left(t_{\text {comb }}=970^{\circ} \mathrm{C}\right.$, ).

\section{2. $\mathrm{NO}_{\mathrm{x}}$ emission during flameless combustion of product gases generated in the BFB gasifier}

In order to investigate if similar dependencies described in Section 3.1 can also be observed using product gases generated from biomass gasification, a series of experiments using wood pellets and rape cake pellets as a gasifier feedstock were conducted. The product gas generated in the gasifier was subsequently combusted using the flameless burner. During the experiments the product gas composition, including $\mathrm{NH}_{3}, \mathrm{HCN}$ and the flue gas composition were measured simultaneously. The composition of the product gas from gasification process can not be as precisely controlled as synthetic gas from a mixing unit. Therefore, to influence the product gas composition the solid bio-fuels were gasified at $750{ }^{\circ} \mathrm{C}$ and $875^{\circ} \mathrm{C}$ with an air ratio of 0.15 and 0.22 in the case of wood pellets and 0.22 in the case of rape cake pellets.

Figure 6 shows the measured hydrocarbon concentrations for both fuels for all tested operating gasifier parameters. With a rising temperature and air ratio the total amount of hydrocarbons was similar and decreased slightly for both fuels. During the gasification of rape cake pellets much higher amounts of $\mathrm{C}_{2} \mathrm{H}_{4}$ were present in the product gas in comparison to wood pellets product gas. Higher gaseous hydrocarbons than $\mathrm{C}_{3} \mathrm{H}_{6}$ and tar were not measured.

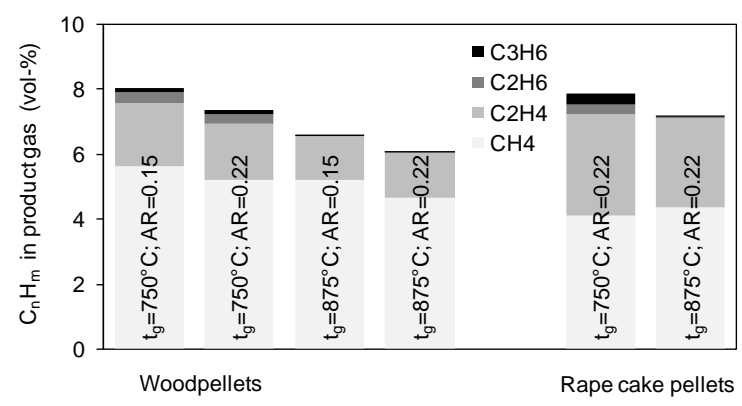

Figure 6. Hydrocarbon concentrations in the product gas during wood and rape cake pellets gasification.

\subsubsection{Fuel-NO $\mathrm{N}_{\mathrm{x}}$ precursors and $\mathrm{NO}_{\mathrm{x}}$ emission -wood pellets}

The measurement results of fuel $\mathrm{NO}_{\mathrm{x}}$ precursors obtained during wood pellets gasification are presented in Figure 7. Ammonia was the main nitrogen containing compound present in the gas. Its concentration increased with the gasifier temperature. The concentration of $\mathrm{HCN}$ behaves in a quite opposite manner as it decreases with increasing temperature. The influence of the gasifier air ratio was minor. However, the concentration of both of the fuel- $\mathrm{NO}_{\mathrm{x}}$ precursors shows a tendency to increase with higher gasifier air ratio and temperature.

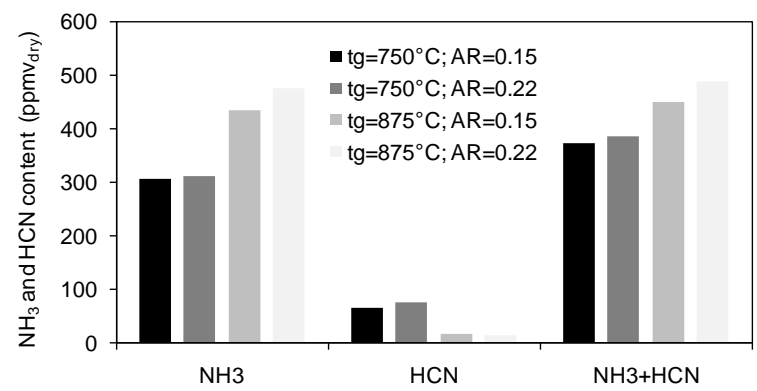

Figure 7. $\mathrm{NH}_{3}$ and $\mathrm{HCN}$ concentrations in the wood pellets gasification product gas.

The product gases were combusted in the flameless burner at the average combustion chamber temperature of $1050{ }^{\circ} \mathrm{C}$. Although the quality and quantity of the product gas was changing due to gasification process instabilities the combustion process was very stable. The amount of combustion air was varied, resulting in flue gas excess oxygen in the range between 1 to 8 vol- $\%$. Complete combustion was first observed at 1.5 vol- $\% \mathrm{O}_{2}$ in the flue gas, much earlier than expected. By further decreasing excess oxygen, particularly below 1 vol- $\%$, a rapid increase in $\mathrm{CO}$ emissions was measured. Figure 8a shows the $\mathrm{NO}_{\mathrm{x}}$ emissions observed during the experiments. The black crosses represent $\mathrm{NO}_{\mathrm{x}}$ emissions while burning product gas generated at a gasifier temperature of $750{ }^{\circ} \mathrm{C}$, whereas the grey crosses show the emissions achieved at a gasifier temperature of $875^{\circ} \mathrm{C}$. The gasifier air ratio in both cases was 0.15 . The $\mathrm{NO}_{\mathrm{x}}$ emissions are plotted against the excess oxygen in the flue gas. 

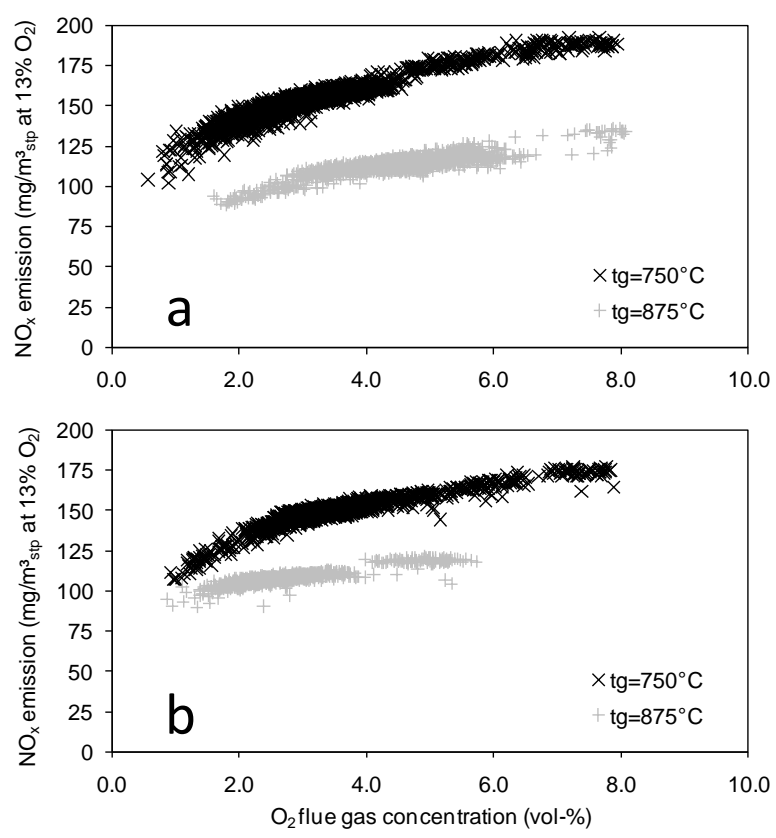

Figure 8. $\mathrm{NO}_{x}$ emission during product gas combustion from wood pellets gasification; $a$ - gasification air ratio $0.15, b$ - gasification air ratio 0.22

Although, the $\mathrm{NH}_{3}$ and $\mathrm{HCN}$ content in the product gas generated at $875{ }^{\circ} \mathrm{C}$ was higher, the emissions of $\mathrm{NO}_{\mathrm{x}}$ are significantly lower. Due to lower hydrocarbon concentrations much less of nitrogen containing compounds in the product gas are converted to $\mathrm{NO}_{\mathrm{x}}$. Very similar results were observed for a higher gasifier air ratio. The results are presented in Figure 8b. Also in this case a higher $\mathrm{NO}_{\mathrm{x}}$ emission level was measured during the combustion of product gases generated at a lower gasifier temperature, thus containing more hydrocarbons. Higher excess oxygen during combustion slightly enhanced the $\mathrm{NO}_{\mathrm{x}}$ formation. The influence of the gasifier air ratio was minor. However with a higher amount of gasification air the emissions were slightly lower. The results also confirm that during combustion of gasifier product gases the content of hydrocarbons is crucial for the ammonia and hydrogen cyanide conversion ratios. The calculated conversion ratios for combustion of wood pellets are presented in Figure 9. The conversion ratio values higher than one indicate that a certain percentage of $\mathrm{NO}_{\mathrm{x}}$ emissions are not originating from the fuel nitrogen. It can be assumed that this part of $\mathrm{NO}_{\mathrm{x}}$ emissions is a thermal- $\mathrm{NO}_{\mathrm{x}}$ which mostly depends on the temperature and its contribution to the total $\mathrm{NO}_{\mathrm{x}}$ emissions is the same for all tested conditions and fuels. Since the exact amount of the thermal part of $\mathrm{NO}_{\mathrm{x}}$ is unknown it could not be extracted from the total $\mathrm{NO}_{\mathrm{x}}$ emissions.

\subsubsection{Fuel-NO $\mathrm{N}_{\mathrm{x}}$ precursors and $\mathrm{NO}_{\mathrm{x}}$ emission -rape cake pellets}

Contrary to wood pellets the rape cake pellets contain a high amount of fuel-bound nitrogen. Therefore, high concentrations of fuel- $\mathrm{NO}_{x}$ precursors in the gasifier product gas and accordingly high $\mathrm{NO}_{\mathrm{x}}$ concentrations in the flue gas were expected. The results are presented in Figure 10 .

The concentrations of ammonia and hydrogen cyanide measured in the product gas were much higher than in the case of wood pellets gasification. Concentrations up to 35000 ppmv $_{\text {dry }}$ were observed. Contrary to results obtained with wood pellets, a higher $\mathrm{NH}_{3}$ concentration and a lower
HCN concentration were measured in the product gas generated at a lower gasifier temperature. The total concentration of both fuel- $\mathrm{NO}_{\mathrm{x}}$ precursors was lower at higher gasifier temperatures. The product gas was subsequently combusted using the flameless burner. The average combustion chamber temperature of $1050{ }^{\circ} \mathrm{C}$ was the same as that during the combustion of the wood pellets product gas. The amount of combustion air was varied in order to investigate the influence of the burner air ratio on $\mathrm{NO}_{\mathrm{x}}$ emissions. In the case of the rape cake pellets product gas, complete combustion was possible beginning at an excess oxygen level of 2 vol- $\%$. The $\mathrm{NO}_{\mathrm{x}}$ emissions were about one order of magnitude higher in comparison to wood pellets product gas combustion. The results are presented in Figure 11. Similarly to the wood pellets case higher $\mathrm{NO}_{\mathrm{x}}$ emissions were measured at a lower gasifier temperature. The difference was growing with the excess oxygen in the flue gas. A higher combustion air ratio significantly enhanced the $\mathrm{NO}_{\mathrm{x}}$ formation.

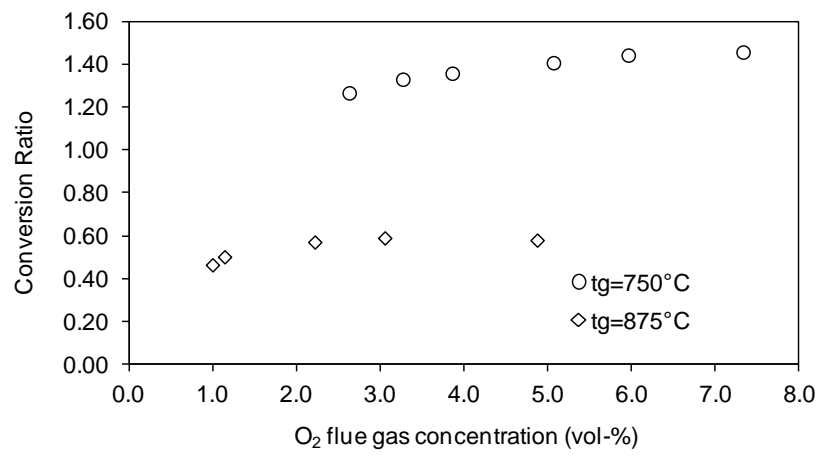

Figure 9. $\mathrm{NH}_{3}$ and $\mathrm{HCN}$ to $\mathrm{NOx}$ conversion ratios during product gas combustion from wood pellets gasification $(A R=0.22)$.

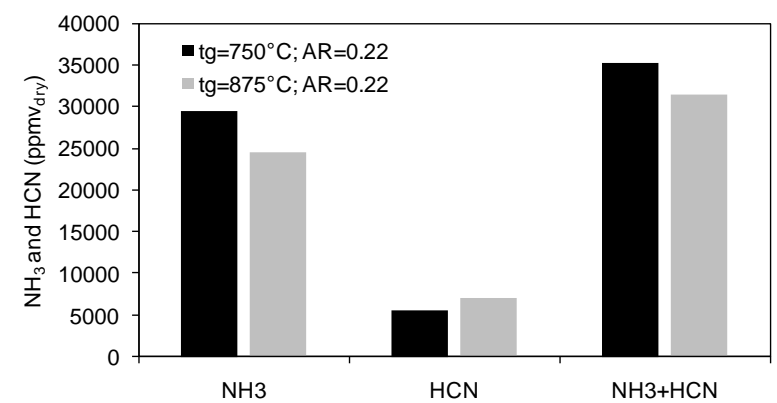

Figure 10. $\mathrm{NH}_{3}$ and $\mathrm{HCN}$ concentrations in the rape cake pellets gasification product gas.

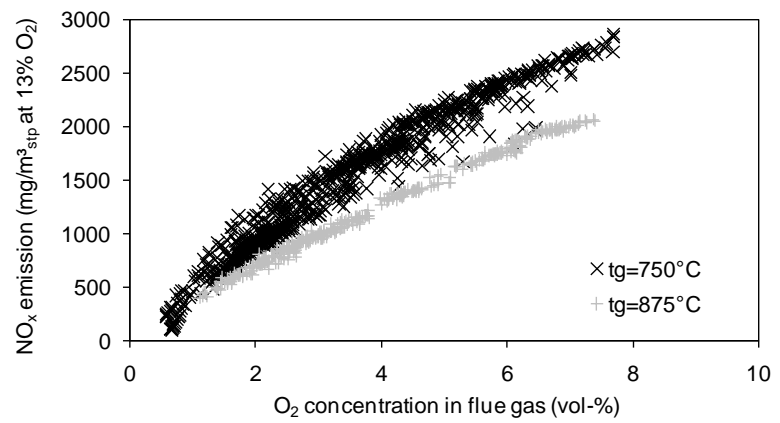

Figure 11. $\mathrm{NO}_{x}$ emission during product gas combustion from rape cake pellets gasification $(A R=0.22)$ 
The lower $\mathrm{NO}_{\mathrm{x}}$ emissions at a higher gasifier temperature were not only observed because of the lower concentration of $\mathrm{NO}_{\mathrm{x}}$ precursors in the product gas. Similar to the wood pellets experiments this case also saw lower hydrocarbon concentrations lead to lower conversion ratios of fuel-nitrogen. Figure 12 shows the calculated conversion ratios for product gas from rape cake pellets gasification.

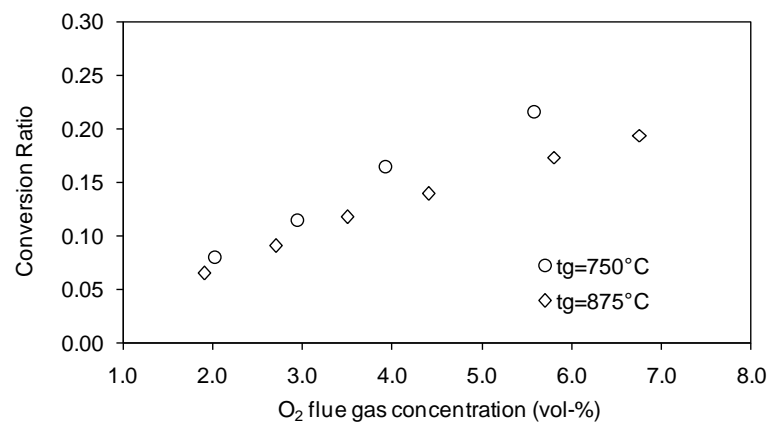

Figure 12. $\mathrm{NH}_{3}$ and $\mathrm{HCN}$ to $\mathrm{NOx}$ conversion ratios during product gas combustion from rape cake pellets gasification $(A R=0.22)$

The conversion ratios were calculated using Eq. (1). The conversion ratios calculated for combustion of product gases generated at the gasifier temperature of $875^{\circ} \mathrm{C}$ are lower than those at $750{ }^{\circ} \mathrm{C}$ in the whole investigated range of excess oxygen. The difference between the values for the two temperatures increases with increasing excess oxygen in the flue gas.

\section{Discussion}

Presented results show that during flameless combustion of $\mathrm{N}$-containing gases, the fuel- $\mathrm{N}$ to $\mathrm{NO}_{\mathrm{x}}$ conversion ratio strongly depends on the hydrocarbon concentrations. This phenomenon can be explained by the results obtained in previous modeling studies of the authors (Zieba et al, 2009a). They examined the ammonia behavior during flameless combustion of methane-free and methanecontaining ammonia doped gases using detailed chemistry. It has been found that the presence of methane strongly influences the ignition behavior and thus the location and the stoichiometry under which the ammonia reacts. In the presence of methane, due to the longer ignition time, ammonia contained in the fuel is reacting with delay in the fuel-lean. Whereas during combustion of methane-free gases, reactions occur rapidly and ammonia decomposes in a substoichiometric region of the reaction zone. In Choudhuri et al., (2003) an investigation of the combustion characteristics of hydrogen-hydrocarbon hybrid fuels is presented. This study confirms that the ignition delay can be significantly influenced by hydrocarbons. Moreover, (Skreiberg et al., 2004) investigated the ammonia chemistry below $1400 \mathrm{~K}$. They also reported that methane in relatively low concentrations can strongly inhibit the ammonia conversion under fuel-rich conditions. Increasing the methane or hydrocarbon content in the fuel can see ammonia and hydrocarbons start to compete for the same radicals occurring in the combustion process. Therefore, the decomposition of ammonia can be shifted toward the fuellean side of the combustion, thus enhancing the conversion to $\mathrm{NO}_{\mathrm{x}}$.

\section{Conclusions}

The presented experimental studies show the fate of ammonia and hydrogen cyanide during flameless combustion of different low calorific value gases. The first series of experiments in which ammonia doped synthetic gases were burned under flameless conditions showed that depending on the gas composition, large differences in the conversion of $\mathrm{NH}_{3}$ to $\mathrm{NO}_{\mathrm{x}}$ can occur. In particular, the methane in low concentrations influences the ammonia to $\mathrm{NO}_{\mathrm{x}}$ conversion. The lowest $\mathrm{NO}_{\mathrm{x}}$ emissions and therefore the lowest conversion ratios were measured while burning methane-free gas. A rapid increase of NOx emissions could already be observed at the lowest investigated methane concentrations. The NOx emissions increased with increasing methane concentrations in the whole investigated range. The tested $\mathrm{CO} / \mathrm{H}_{2}$ ratios in the fuel had a minor influence on the conversion of ammonia to $\mathrm{NO}_{\mathrm{x}}$. During the second series of experiments, product gases generated from two different solid bio-fuels in a BFB gasifier were burned in the flameless burner. The goal of these studies was to show the dependencies between gasifier operating parameters and thus the composition of the product gas and final $\mathrm{NO}_{\mathrm{x}}$ emissions during subsequent flameless combustion. The results shows the same tendencies observed during tests with ammonia doped synthetic gases. Also in this case the fuel nitrogen conversion was influenced by the product gas composition. According to investigated gasifier parameters the amount of hydrocarbons and fuel- $\mathrm{NO}_{\mathrm{x}}$ precursors was changing. In the case of wood pellets product gas combustion, much higher $\mathrm{NO}_{\mathrm{x}}$ emissions were observed with lower gasifier temperatures and thus with higher hydrocarbons concentrations in the product gas. This was observed even when the concentration of $\mathrm{NH}_{3}$ and $\mathrm{HCN}$ was lower at a lower gasifier temperature. In the case of nitrogen-rich rape cake pellets, much higher concentrations of $\mathrm{NH}_{3}$ and $\mathrm{HCN}$ were measured in comparison to wood pellets. This case also saw higher hydrocarbon concentrations lead to higher conversion rates of $\mathrm{NH}_{3}$ and $\mathrm{HCN}$ to $\mathrm{NO}_{\mathrm{x}}$. In all cases a higher combustion air ratio enhanced the $\mathrm{NO}_{\mathrm{x}}$ emissions. This was observed particularly during the combustion of the nitrogen-rich rape cake pellets product gas.

\section{References}

Wünning J.A. and Wünning J.G., 1997, Flameless oxidation to reduce thermal-NO formation, Prog. Energy Combust. Sci. 23, pp.81-94.

Becidan M., Skreiberg Ø., Hustad J.E., 2007, $\mathrm{NO}_{\mathrm{x}}$ and $\mathrm{N}_{2} \mathrm{O}$ Precursors $\left(\mathrm{NH}_{3}\right.$ and $\left.\mathrm{HCN}\right)$ in Pyrolysis of Biomass Residues, Energy Fuels 21, p. 1173-1180, (2007).

Cavaliere A., De Joannon M., 2004, Mild Combustion, Prog. Energy Combust. Sci. 30, pp. 329-366.

Choudhuri A.R., Gollahalli S.R., 2003, Characteristics of hydrogen-hydrocarbon composite fuel turbulent jet flames, Int. J. Hydrogen Energy 28, pp 445 - 454.

Galletti C., Parente A., Tognotti L., 2007, Numerical and experimental investigation of a mild combustion burner, Combust. Flame 151, pp. 649-664.

German Standard DIN 38406-E5, 1983, Methods for the examination of water, waste water and sludge; determination of ammonia-nitrogen (E5). 
German Standard DIN 38405-D13, 1981, Methods for the examination of water, waste water and sludge; determination of cyanides (D13).

Leppälahti J., Koljonen T., 1995, Nitrogen evolution from coal, peat and wood during gasification: Literature review, Fuel Proc. Tech. 43, pp. 1-45.

Schuster A., Zieba M., Wünning J.G., Scheffknecht G., 2007, "Optimisation of conventional biomass combustion system by applying flameless oxidation", Proceedings of $15^{\text {th }}$ IFRF Members' Conference, Pisa.

Schuster A., Zieba M., Scheffknecht G., Wünning J.G. 2007, "Application of FLOX ${ }^{\circledR}$ Technology for the utilisation of low-grade biofuels", Proceedings of $15^{\text {th }}$
European Biomass Conference, Berlin, Germany, pp. 1703-1706.

Skreiberg Ø., Kilpinen P., Glarborg P., 2004, Ammonia chemistry below $1400 \mathrm{~K}$, Combust. Flame 136, pp. 501518.

Zieba. M, Schuster A., Scheffknecht G., 2009a, Influence of gas composition on ammonia to $\mathrm{NO}_{\mathrm{x}}$ conversion during flameless combustion of low calorific value gases, Proceedings of $16^{\text {th }}$ IFRF Members' Conference, Boston.

Zieba. M. Brink. A., Schuster A., Hupa M., Scheffknecht G., 2009b, Ammonia chemistry in a flameless jet, Combust. Flame 156, pp. 1950-1956. 